\title{
Retraction Note to: Circular RNA ABCB10 promotes hepatocellular carcinoma progression by increasing HMG20A expression by sponging miR-670-3p
}

Yu Fu' ${ }^{1}$ Limin $\mathrm{Cai}^{2}$, Xuexue Lei ${ }^{1}$ and Dunwei Wang ${ }^{2^{*}}$

\section{Retraction to: Cancer Cell Int (2019) 19:338 \\ https://doi.org/10.1186/s12935-019-1055-z}

The Editor-in-Chief has retracted this article [1] due to lack of evidence that the study has received ethics approval. After publication it has come to the Editor's attention that in the body of the article the authors state that their study was approved by the First Hospital of Jilin University Research Ethics Committee. However, in the Ethics declarations section, the authors state that their study was approved by the Ethics Committee of the Maternity and Child Care Center of Liuzhou. The authors have not provided documentation of approval from an ethics committee for this study. The authors have not responded to any correspondence regarding this retraction.

\section{Author details}

${ }^{1}$ Department of Hepatobiliary and Pancreas Surgery, The First Hospital of Jilin University, Changchun 130021, Jilin, People's Republic of China. ${ }^{2}$ Department of Anesthesiology, The First Hospital of Jilin University, No. 71 Xinmin Street, Changchun 130021, Jilin, People's Republic of China.

Published online: 06 October 2020

\begin{abstract}
Reference
1. Fu Y, Cai L, Lei X, Wang D. Circular RNA ABCB10 promotes hepatocellular carcinoma progression by increasing HMG20A expression by sponging miR-670-3p. Cancer Cell Int. 2019;19:338. https://doi.org/10.1186/s1293 5-019-1055-z.
\end{abstract}

\section{Publisher's Note}

Springer Nature remains neutral with regard to jurisdictional claims in published maps and institutional affiliations.

(C) The Author(s) 2020. This article is licensed under a Creative Commons Attribution 4.0 International License, which permits use, sharing, adaptation, distribution and reproduction in any medium or format, as long as you give appropriate credit to the original author(s) and the source, provide a link to the Creative Commons licence, and indicate if changes were made. The images or other third party material in this article are included in the article's Creative Commons licence, unless indicated otherwise in a credit line to the material. If material is not included in the article's Creative Commons licence and your intended use is not permitted by statutory regulation or exceeds the permitted use, you will need to obtain permission directly from the copyright holder. To view a copy of this licence, visit http://creativeco mmons.org/licenses/by/4.0/. The Creative Commons Public Domain Dedication waiver (http://creativecommons.org/publicdomain/ zero/1.0/) applies to the data made available in this article, unless otherwise stated in a credit line to the data. 